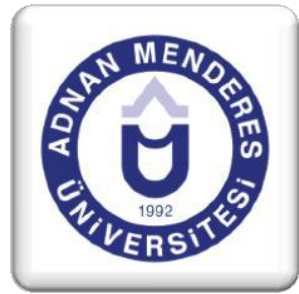

\section{Fen Bilimleri ve Sınıf Öğretmenlerinin Proje Tabanlı Öğretim Yapabilme Özyeterlilikleri Ü̉zerine Bir Ölçek Geliştirme Çalışması ${ }^{1}$}

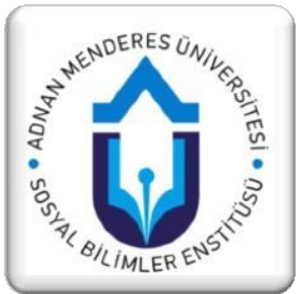

\title{
ÖZET
}

$\mathrm{Bu}$ çalışmanın amacı, fen bilimleri ve sınıf öğretmenlerinin proje tabanlı öğretim yapabilme özyeterliliklerini ölçmede kullanılabilecek geçerli ve güvenilir bir ölçek geliştirmektir. Ölçeğin geçerlilik ve güvenirlik çalışmaları, 2012-2013 yılı Malatya İli Milli Eğitim Müdürlügü̈’ne bağlı ortaokul ve ilkokullarda görev yapmakta olan 61 fen ve teknoloji öğretmeni ile 195 sınıf öğretmeninin katılımıyla gerçekleştirilmiştir. Ölçeğin yapı geçerliğini belirlemek amacıyla yapılan açımlayıcı faktör analizi sonucunda ölçeğin faktör yüklerinin 0.54 ile 0.80 arasında değişen 5 faktörden oluştuğu ve Kaiser Mayer Olkin (KMO) değeri 0.86, güvenirlik çalışması için hesaplanan iç tutarlı1ık katsayısı Cronbach Alpha değeri ise 0.92 bulunmuştur. Bu faktörler sırasıyla "Proje Sürecine Hâkimiyet, Rehberlik Etme", "Planlama, Hazırlık ve Yansıtma", "Uygulama ve Değerlendirme", "Dönüt Verme, Alternatif Değerlendirme", "Grup Süreci ve Üst Düzey Öğrenme” olarak adlandırılmıştır. Bu çalışma sonucunda toplam varyansın \%66' sını açıklayan, 24 maddeden oluşan 5'li likert tipi bir ölçek elde edilmiştir. Bu varyansın \% 40 'ını birinci, \%8'ini ikinci, \%7'sini üçüncü, \%5'ini dördüncü ve \%6'sını beşinci faktör oluşturmaktadır. Geçerlilik ve güvenilirlik çalışmaları sonucunda ulaşılan bulgular, ölçeğin geçerli ve güvenilir olduğunu göstermektedir. Bu ölçeğin; proje tabanlı öğretim yapabilme özyeterliliklerinin belirlenmesinde, öğretmenler için önemli bir araç olduğu düşünülmektedir.

Anahtar Kelimeler: Proje Tabanlı Öğretim, Fen Bilimleri ve Sınıf Öğretmeni, Özyeterlilik.

\section{A Study On Developing A Scale For Science and Primary Teacher's Self Efficacy Regarding Providing Project-Based Teaching}

\begin{abstract}
The aim of this study is to develop a valid and reliable scale which can be used to assess self efficacy of science and primary teachers teachers to provide project based teaching. Validity and reliability studies of the scale were conducted with participation of 61 science teachers and 195 class teachers working in the secondary and primary schools in Provincial Directorate of National Education of Malatya between 2012 and 2013. As a result of the exploratory factor analysis performed to determine construct validity of the scale, it was found that factor loads of the scale consisted of 5 factors ranging between 0.54 and 0.80 and Kaiser Mayer Olkin (KMO) value was 0.86, and Cronbach's Alpha value of internal consistency coefficient calculated for reliability validity was 0.92 . These factors were called as "Mastery on Process of the Project, Guiding", "Planning, Preparation, and Reflection", "Practice and Evaluation", "Feedback, Alternative Assessment", and "Group Process and High Level Learning", respectively. A 5-point likert-type scale, which explains $66 \%$ of total variance and consists of 24 items, was obtained after this study. $40 \%, 8 \%, 7 \%, 5 \%$, and $6 \%$ of this variance were comprised of the first factor, the second factor, the third factor, the fourth factor, and the fifth factor, respectively. Results obtained as a result of validity and reliability studies indicate that the scale is valid and reliable. This scale is considered as an important tool for teachers to determine their self-efficacy regarding providing project-based teaching.
\end{abstract}

Key Words: Project Based Learning, Science and Primary Teacher, Self Efficacy.

\footnotetext{
${ }^{1}$ Bu çalışma "Fen Bilgisi Öğretmenlerinin Proje Tabanlı Öğretim Yapabilmelerine İlişkin Özyeterlilikleri” adlı yüksek lisans tez çalışmasının bir bölümüdür.

${ }^{2}$ Doç. Dr., İnönü Üniversitesi, Matematik ve Fen Bilimleri Eğitimi Bölümü, fatma.mutlu@inonu.edu.tr

${ }^{3}$ Hanımın Çiftliği 100. Yıl Atatürk Ortaokulu, Battalgazi, Malatya nurhan_yzteach@hotmail.com
} 


\section{Giriș}

Fen bilgisi eğitiminin temel amaçları; öğrencilere yaratıcı ve eleştirel düşünme yetisinin kazandırılması, öğrencilerin modern bilimsel düşünmenin temelinde yer alan kavramsal bütünlükleri anlamalarının sağlanması, problemlerin ortaya konulmasında öğrencilere özgüven kazandırılması ve bu problemlerin öğrenciler tarafindan cevaplandırılabilmesi ve çözümlenebilmesi için yol gösterilmesi şeklinde ifade edilmektedir (Yaman, 2005). Nitelikli bireyler yetiştirebilmek adına uygulanması gereken, öğrencinin aktif olduğu pek çok öğretim yaklaşımı bulunmaktadır. Bu şekilde öğrencinin bilgiye ulaşmasını sağlayan yaklaşımlardan biri de proje tabanlı öğrenmedir (PTÖ). PTÖ; tasarı geliştirme, hayal etme, planlamaya, kurgulamaya dayalı gerçek yaşam durumlarını sınıf ortamına taşıyarak onları projeler çerçevesinde çalıştıran, bunu yaparken de disiplinler arası ilişki kuran bir anlayıştır (Erdem 2002).

PTÖ yaklaşımı; fen ve teknoloji alanında söz konusu olan ve sanayi toplumundan bilgi toplumuna geçişin temelinde yer alan değişimlerin fen derslerine yansitılabilmesine olanak tanımakta olup bu değişime ayak uydurmak isteyen ülkeler, fen bilgisi eğitiminin PTÖ yaklaşımı kapsamında sürdürülmesine daha fazla önem vermektedirler (Akgün, 2004). PTÖ yaklaşımı temelinde öğrenme-öğretme etkinliklerini düzenleyen öğretmenlerin, öğrencilerin belirtilen bu nitelikleri kazanabilmelerini olanaklı hale getirebilmek adına araştırma metotlarını bilmeleri ve daha öncesinde de uygulamış olmaları gerekmektedir. Yine öğretmenlerin proje konularını öğrencilerin seviyelerine uygun olarak tespit edebilmeleri, çalışma gruplarını oluşturmada gereği gibi hareket edebilmeleri ve hem süreci hem de ürünü doğru olarak değerlendirilebilmeleri için gereken niteliklere sahip olmaları gerekmektedir. PTÖ yaklaşımının başarısı, bu yaklaşım temelinde uygulamada bulunacak olan öğretmenlerin ne denli etkili ve verimli olabildikleri ile belirlenmiş olacaktır (Pektaş ve Arslan, 2009).

Yapılan araştırmalar, sınıflarında PTÖ yöntemini uygulayan öğretmenlerin, birçok zorlukla karşılaştığını göstermektedir (Mergendoller ve Thomas, 2001). Bu zorlukların asıl uygulayıcıları olan öğretmenlerin PTÖ konusundaki öz yeterliliklerinin tespit edilmesi, öğretmenlerin, PTÖ yaklaşımı ile ilgili hangi aşamada kendilerini yetersiz hissettikleri ve bunların giderilmesi yönünde neler yapılması gerektiği hakkında fikir verecektir. Öz yeterlilik kavramı ilk kez Bandura tarafından vurgulanmıştır. Bandura özyeterlilik (selfefficacy) kavramını, davranışların oluşmasında etkili olan bir nitelik ve "bireyin, belli bir performansı göstermek için gerekli etkinlikleri organize edip, başarılı olarak yapma kapasitesi hakkında kendine ilişkin yargısı" olarak tanımlamaktadır. (Bandura 1982; Bandura, 1997; Zimmerman, 1995). Literatürde bu konu "öğretmen özyeterliliği" kavramı ile ilişkilendirilmekte ve tanımları çeşitlilik göstermektedir: Self-Efficacy kavramı Türkçeye farklı şekillerde tercüme edilerek kullanılmıştır. Kavramın "yetkinlik beklentisi", "özyeterlik beklentisi”, “öz-yeterlik inancı”, "öz-yeterlik algısı”, "öz-yetkinlik”, “öz-yeterlik” gibi çevirileri olduğu görülmektedir (Aksoy ve Diken, 2009; Tabancalı ve Çelik, 2013). Farklı kavramlar kullanılsa da bu çalışmaların hepsi Bandura'nın özyeterlik (self-efficacy) kavramına atıfta bulunmaktadır. Tschannan-Moran ve Woolfolk Hoy (2001) ögretmen özyeterlilik kavramını; "zor öğrenci ve düşük motivasyona sahip öğrenciler de dahil, her öğrenciye öğretebilme kararlılığı" olarak ifade etmişlerdir. Korkmaz (2004)' a göre ise özyeterlik inançları; insanların kendileri için belirledikleri amaçları, bu amaçlara ulaşmak için ne kadar çaba harcayacaklarını, amaçlarına ulaşmak için karşılaştıkları güçlüklerle ne kadar süre yüz yüze kalabileceklerini ve başarısızlık karşısındaki tepkilerini etkilemektedir. 
Öğretmenlerin ve öğretmen adaylarının özyeterlilikleri ile ilgili çalışmalar son y1llarda giderek artmaktadır. Hem öğretmen adaylarının (Aydemir, Duran, Kapıdere, Kaleci ve Aksoy, 2014; Çapri ve Çelikkaleli, 2008; Elkatmış, Demirbaş ve Ertuğrul, 2013; Nakip ve Özcan, 2016; Özdemir, 2008; Uysal ve Kösemen, 2016; Yeşilyurt, 2013) hem de öğretmenlerin (Ekici, 2006; Gençtürk ve Memiş, 2010; Kıvrak ve Dönmez, 2013; Kutluca ve Aydın, 2016) özyeterliliklerine ilişkin pek çok araştırma gerçekleştirilmiştir. Fen bilgisi öğretmenlerin PTÖ yaklaşımına yönelik özyeterliliğe sahip olmaları; fen bilgisi derslerine ilişkin öğretim amaçlarına ulaşılabilmesi, öğrencilerin ilgi ve istekleri doğrultusunda belirlenmiş olan ünite ve konuların yine öğrencilerin aktif katılımları ile sonuçlandırılması açısından önem taşımaktadır (Akgün, 2004). PTÖ yaklaşımı sayesinde öğrenciler, kendi ilgi alanları çerçevesinde ve kendi belirledikleri sorularla öğretim sürecini takip etmiş olabilecekler ve çözümlere de kendi başlarına aldıkları kararlar neticesinde ulaşacaklardır (Uzun, 2007).

Bununla birlikte PTÖ yaklaşımı, kısa, izole edilmiş ve öğretmen merkezli sınıf uygulamalarının yerine, uzun süreli, disiplinlerarası, gerçek dünya/yaşam konu ve uygulamalarıyla bütünleştirilmiş ve en önemlisi de öğrenci merkezli öğretim aktivitelerini temel alan bir yaklaşımdır. Bu doğrultuda öğretmenlerin de PTÖ yaklaşımı ile ilgili özyeterlilikleri, öğrencilerin öğretim sürecinde gereği gibi yetiştirilebilmelerine olanak sağlamış olacaktır (Ayvacı ve Çoruhlu, 2010). Öğretmenlerin PTÖ yaklaşımı ile ilgili özyeterlilik düzeyleri ve özyeterlilik algıları; hem derslerin amaçlarına uygun olarak sürdürülmesinde hem de bu çerçevede, öğrencilere mantıksal düşünme becerisi kazandırılabilmesinde, çağdaş eğitim teknolojilerini içeren uygulamaların zorluklarıyla mücadele edebilmede ve başarı düzeyleri yüksek bireylerin yetiştirilebilmesinde önem arz etmektedir.

Yapılan araştırmalarda çeşitli fen konularında PTÖ uygulaması ile öğrenci genel özyeterliliklerinin incelendiği birkaç araştırmaya rastlanmış (Çıbık ve İnce Aka, 2016; Tonbuloğlu, Aslan, Altun ve Aydın, 2013), ancak öğretmenlerin PTÖ uygulaması yapabilirliklerine ilişkin özyeterliliklerini belirlemekte kullanılabilecek bir ölçme aracına ulaşılamamıştır. Bu kuramsal bilgilerden hareketle çalışmamızda amaç, öğretmenlerin PTÖ yapabilme özyeterliliklerini ölçmede kullanılabilecek nitelikli bir ölçek geliştirmektir. Geçerlik ve güvenirlik çalışması yapılan bu ölçek öğretmenlerin PTÖ özyeterliliklerini belirlemeyi amaçlamaktadır.

\section{Yöntem}

\subsection{Desen}

Öğretmenlerin PTÖ uygulamalarına ilişkin özyeterlilik algılarının betimlenebilmesinde kullanılabilecek geçerli ve güvenilir bir özyeterlilik ölçeği geliştirilmesini amaçlayan bu araştırma, bir ölçek geliştirme çalışması olarak desenlenmiştir.

Ölçek geliştirme işlemleri; madde havuzu oluşturma, uzman görüşüne başvurma, ön deneme aşaması ve geçerlik ve güvenirlik analizi sırasına uyularak gerçekleştirilmiştir (Nuhoğlu, 2008). Çalışmada öğretmenlerin PTÖ özyeterliliklerini belirleyen beşli likert tipi modele uygun şekilde tasarlanmış bir ölçek geliştirmek amacıyla geçerlik ve güvenirlik işlemleri gerçekleştirilmiştir.

\section{2. Çalıșma Grubu}

Araştırmanın çalışma grubunu 2012-2013 yılı Malatya İli Milli Eğitim Müdürlügü̆'ne bağlı ortaokul ve ilkokullarda görev yapmakta olan 61 fen bilgisi ve 195 sinıf öğretmeni oluşturmaktadır. Bu çalışmada amaçlı örnekleme yöntemlerinden zaman, para ve işgücü 
açısından var olan sınırlılıklar nedeniyle "uygun örnekleme" yöntemine göre örneklem alınmıştır.

\subsection{Veri Toplama Aracının Geliştirilmesi}

Bu aşamada PTÖ' ye yönelik özyeterlilik ölçeğinin oluşturulması ile ilgili literatür taranarak, ölçek geliştirme çalışmaları incelenmiştir. Ölçek 5'li likert tarzında (Kesinlikle katılmıyorum-Katılmıyorum-Kararsızım-Katılıyorum-Kesinlikle katılıyorum) hazırlanmıştır. Likert tipi ölçekler günümüzde kullanışlı olmaları, dereceleme düzeyini artırdıkça eşit aralık ölçeğinde ölçme sonuçları vermeleri nedeniyle karşımıza sıklıkla çıkan ölçek türüdür (Tezbaşaran, 2008).

\section{4. Özyeterlilik Maddeleri Havuzunu Oluşturma Aşaması}

PTÖ’ye ilişkin özyeterlilik maddeleri tasarlanmadan önce literatürde yer alan özyeterlilik, ölçek geliştirme ve PTÖ ile ilgili öğretmenlerin sorumlulukları ve bu süreçte yaşanan sorunlar hakkında yapılan çalışmalar detaylı bir şekilde incelenmiştir. Ayrıca İnönü Üniversitesi Eğitim Fakültesi Fen Bilgisi Öğretmenliği Programı’na kayıtlı 4. sınıf öğrenci grubunun (80 öğrenci), PTÖ ile ilgili hazırlanan açık uçlu sorulara verdiği yanıtlar da incelenmiştir. Özyeterlilik maddeleri oluşturulurken, ifade edilişi, kapsamı, ilgili yapıyı ölçüp ölçmemesi gibi dikkat edilmesi gereken noktalar konusunda hem literatürdeki kuramsal bilgilerden hem de öğrenci yanıtlarından yararlanılarak 75 maddelik 5'li likert tipinde bir deneme formu elde edilmiştir.

Maddelerin belirlenmesinde; olumlu ve olumsuz ifadelerin eşit olmasına, özyeterliliği ölçmesine, PTÖ uygulaması ile ilgili aşamalarda öğretmenlerin sorumluluklarını kapsamasına dikkat edilmiştir.

\subsection{Uzman Görüşüne Başvurma Aşaması}

Literatürde uzman görüşüne başvurma; ölçekteki maddelerin ölçülmek istenilen davranışlar evrenini, hangi oranda açıkladığını göstermek için yapılmaktadır. Bu çalışmada; belirlenmiş olan 75 maddelik deneme formu uzman görüşleri ile ön incelemeden geçirilmiştir. $\mathrm{Bu}$ incelemede özellikle anlaşılırlık, kapsam, olumsuz-olumlu cümle ayrımının doğruluk düzeyi ve maddelerin öğretmenlerin PTÖ’ye yönelik özyeterliliklerini ölçüp ölçmediği üzerinde durulmuştur. Bu kapsamda ölçek maddeleri ile ilgili eğitim bilimleri alanında 5, fen bilimleri alanında doktorası olan 3 uzmanın görüşlerine başvurulmuştur. Ölçek maddeleri ayrıca 5 öğretmenin de incelemesinden geçirilmiştir. Ölçekteki maddeler ifade ve uygunluk açısından yararlı/gerekli/gereksiz şeklinde incelenmiştir. Uzmanlar tarafından uygun görülmeyen maddeler katılım oranının yüksekliğine göre çıkarılmıştır. Gerekli görülen maddeler, üzerinde düzeltmeler yapılarak ölçeğe yeniden uyarlanmıştır.

Ayrıca ölçeğin dil geçerliliği açısından 2 dil bilimciye de başvurulmuştur. Maddeler; yazım kuralları, açıklık, anlaşılırlık yönünden incelenerek gereksiz ifadeler çıkarılmış, gerekli görülen maddeler düzeltme yapılarak ölçeğe alınmıştır. Uzmanlardan alınan görüşler yönünde başlangıçta 75 olan madde sayısı 49 maddeye indirilmiş̧ir. 49 maddelik özyeterlilik ölçeği, pilot uygulama için deneme ölçeği olarak son şeklini kazanmıştır ve uygulamaya hazır hale getirilmiştir.

\section{6. Ön Deneme Aşaması}

49 maddelik özyeterlilik ifadelerini kapsayan deneme ölçeğindeki maddeler 2012-2013 yıl1 Malatya İli Milli Eğitim Müdürlüğü'ne bağlı ortaokul ve ilkokullarda görev yapmakta olan toplam 61 fen ve teknoloji ve 195 sinıf öğretmenine uygulanmıştır. 


\subsection{Verilerin Analizi}

Araştırma grubundan toplanan veriler üzerinde "PTÖ özyeterlilik ölçeği' nin" önce geçerlilik, ardından güvenilirlik analizleri yapılmıştır. Ölçekten elde edilen verilerin istatiksel çözümlenmesinde SPSS 21.0 (Statistical Package for Social Science) paket programı kullanılmıştır.

\section{Bulgular}

\subsection{Geçerlik ve Güvenirlik Analizi}

Elde edilen verilerin, faktör analizi için uygun olup olmadığını belirlemek amacıyla KaiserMeyer-Olkin (KMO) ve Bartlett's Sphericity (BS) Testi sonucunda oluşan analizlere bakılmıştır. Faktör analizi yapabilmek için KMO değerinin 0.60 'dan büyük olması, BS anlamlılık değerinin 0.05 'ten küçük olması gerekmektedir (Büyüköztürk, 2007; Tatlıdil, 2002). KMO, veri yapısının örneklem sayısı açısından faktör analizine uygun olup olmadığını ölçen bir testtir. Kaiser, bulunan değerin 1'e yaklaştıkça mükemmel, 0.50'nin altında ise, kabul edilemez olduğunu belirtmektedir (Tavşanc1l, 2002). KMO ve BS testi sonucunda KMO değerinin 0.86 çıkması, üzerinde çalışılan örneklem büyüklügünün yeterli olduğunu ve veri setinin faktör analizi için mükemmel olduğunu göstermektedir. Ayrıca BS testi sonucunun $\mathrm{x}^{2}=3259.422 ; \mathrm{df}=990, \mathrm{p}<0.05$ çıkması, değişkenler arasında faktör analizi yapmaya yeterli düzeyde bir ilişki olduğunu göstermektedir (Tablo 1).

İstatistik analizi sonucu ölçekteki maddelerin 9'u birinci faktörde, 4'ü ikinci, 5'i üçüncü, 3'er tanesi ise dördüncü ve beşinci faktörlerde toplanmıştır. Literatürdeki uygulamalarda toplam varyansın $\% 50$ ve yukarısı olması kabul edilebilebilir orandır (Altunışık, Coşkun, Bayraktaraoğlu ve Yıldırım, 2005). Ölçeğin, toplam varyansın \% 66'sını açıladığı bulunmuştur. Varyans değeri, uygulamalarla örtüşmektedir. Bu varyansın \% 40'ını birinci, \% 8'ini ikinci, \% 7'sini üçüncü, \% 5'ini dördüncü ve \% 6'sını beşinci faktör oluşturmaktadır (Tablo 1). Bu faktörler sırasıyla "Proje Sürecine Hâkimiyet, Rehberlik Etme", "Planlama, Hazırlık ve Yansıtma", "Uygulama ve Değerlendirme", "Dönüt Verme, Alternatif Değerlendirme", "Grup Süreci ve Üst Düzey Öğrenme” olarak adlandırılmıştır.

Faktörlerin, kapsadığı maddelerle ilişkisinin gücünü gösteren faktör yük değerleri için sınır değer 0.40 olarak kabul edilmiştir (Tsai and Chai, 2005; Yavuz, 2005). Bir maddenin bir yapıyı ya da faktörü iyi ölçtügünü söyleyebilmek için bu faktör yükünün değerinin 0.30 ya da bu değerin üstünde bir değer olması gerekir. 0.30- 0.60 faktör yüküne sahip olan bir madde için yapıyı orta derecede, 0.60 'dan (pozitif ya da negatif) yüksek faktör yüküne sahip olan bir madde için ise yüksek derecede yapıyı ölçtüğü çıkarımı yapılabilir (Kline, 1994).Böylece sadece tek faktörü tanımlayan, 0.40'dan yüksek değer alan maddelerin, faktöre seçilmesi sağlanmıştır. Bu ilkelere göre; ölçeğe ait faktör yük değerlerinin 0.54 ile 0.80 arasında değişmekte olduğu tespit edilmiştir. Elde edilen yük değerleri, maddelerin ilgili olduğu faktörlerle yüksek korelasyon sergilediğini göstermiştir.

Ölçeğin faktör analizi yapıldıktan sonra ölçekteki tüm maddelerin ve her bir alt boyuta ait maddelerin iç tutarlık katsayısını belirten Cronbach Alfa katsayıları hesaplanmıştır. Ölçeğin tümünün güvenirliği 0.92 , alt boyutların güvenirliği ise 0.68 ile 0.91 arasında bulunmuştur. Tablo 1'de belirtildiği gibi faktör analizi sonucunda 24 maddeden oluşan beş faktörlü özyeterlilik ölçeği geliştirilmiştir. Ölçeğin yapı geçerliği için Temel Bileşenler Analizi yöntemlerinden Açımlayıcı faktör analizi ve Varimax dik döndürme tekniği uygulanarak, maddelerin birbiriyle ilişkili ortak değişkenlere yani faktörlere indirgenmesi sağlanmıştır. Böylece ölçekteki maddeler anlamlı kavramsal yapılara dönüşmüştür. Faktör sayısına karar verilirken özdeğeri 1'den büyük 5 faktör seçilmiştir. Tablo 2'de görüldügü gibi faktörlerin 
özdeğerleri sırasıyla; 9.97, 2.01, 1.62, 1.35, ve 1.12'dir. Faktör yapıları belirlenirken özdeğerlere ait çizgi grafiği de dikkate alınmıştır (Şekil 1).

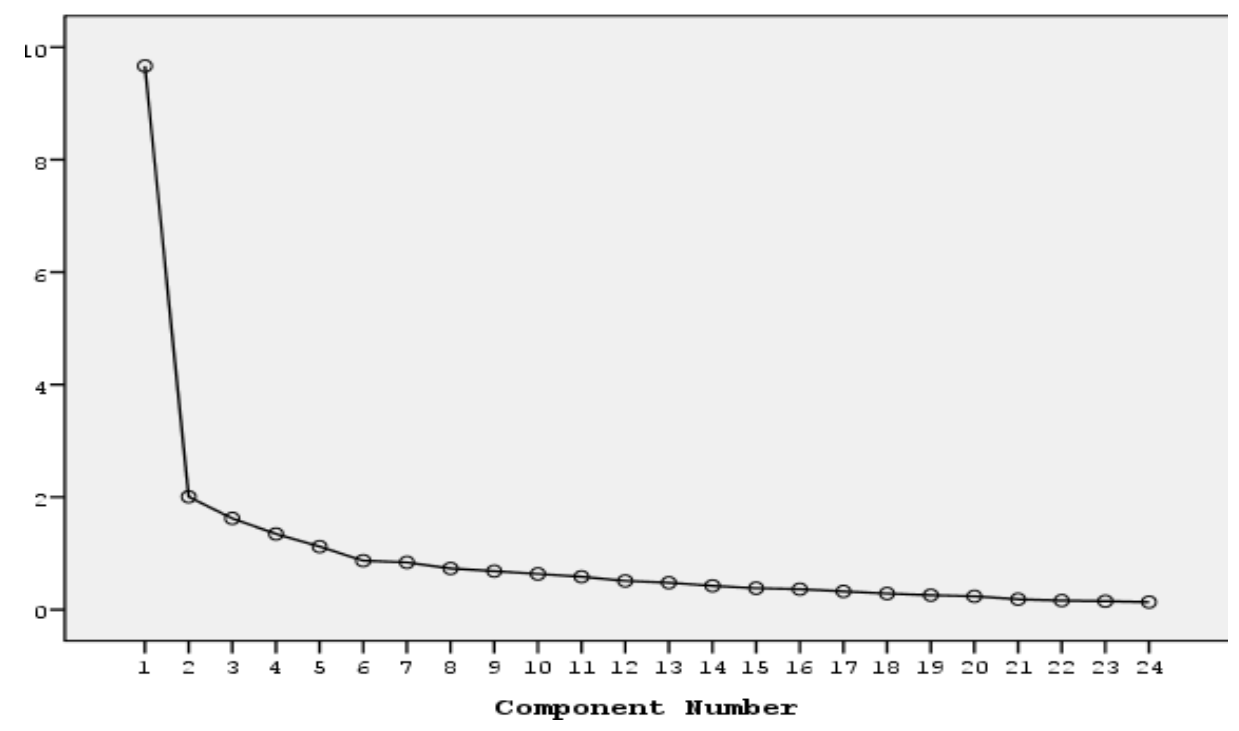

Şekil 1. Faktör Öz Değerlerine Ait Çizgi Grafiği 
Tablo 1. Taslak Ölçeğin Analiz Sonuçları

\begin{tabular}{|c|c|c|}
\hline MADDE & $\begin{array}{l}\text { Faktör } \\
\text { Yükleri }\end{array}$ & \multirow{10}{*}{$\begin{array}{l}\text { 1. Faktörün; } \\
\text { Açıkladığı Varyans: \%40 } \\
\text { Cronbach Alfa }=0.91\end{array}$} \\
\hline $\begin{array}{l}\text { Öğrencilere farklı becerileri kullanabilecekleri proje çalışmaları } \\
\text { hazırlatabilirim. }\end{array}$ & 0.773 & \\
\hline $\begin{array}{l}\text { Öğrencilerimi proje çalışmaları sonunda özgün ürünler üretmeye } \\
\text { teşvik edebilirim. }\end{array}$ & 0.750 & \\
\hline $\begin{array}{l}\text { Öğrencilerimin eksiklerini tamamlamaları ve yanlışlarını } \\
\text { düzeltmeleri için etkili bir biçimde rehberlik edebilirim. }\end{array}$ & 0.725 & \\
\hline $\begin{array}{l}\text { Proje çalışmaları sırasında öğrencilerin edindikleri bilgileri } \\
\text { düzenlemeye yardım edebilirim. }\end{array}$ & 0.687 & \\
\hline $\begin{array}{l}\text { Proje gruplarının araştırma ve çalışma becerilerinin geliştirilmesine } \\
\text { yardım ve rehberlik edebilirim. }\end{array}$ & 0.657 & \\
\hline Öğrencileri yeni projeler üretmeleri konusunda motive edebilirim. & 0.657 & \\
\hline Projeler sonunda ögrrencilerin eksikliklerini tamamlayabilirim & 0.639 & \\
\hline $\begin{array}{l}\text { Proje tabanlı öğretim uygulamalarında bireysel olarak öğrencilerin } \\
\text { araştırma ve çalışma becerilerini geliştirebilirim. }\end{array}$ & 0.596 & \\
\hline Projelerde tüm aşamaları sırasıyla yerine getirebilirim. & 0.591 & \\
\hline $\begin{array}{l}\text { Öğrencilere proje oluşturmanın her aşaması ile ilgili geri bildirim } \\
\text { verebilirim. }\end{array}$ & 0.766 & \multirow{4}{*}{$\begin{array}{l}\text { 2. Faktörün; } \\
\text { Açıkladığı Varyans: } \% 8 \\
\text { Cronbach Alfa }=0.87\end{array}$} \\
\hline $\begin{array}{l}\text { Proje kapsamında öğrencilerin hazırladıkları portfolyoları } \\
\text { değerlendirebilirim. }\end{array}$ & 0.761 & \\
\hline $\begin{array}{l}\text { Projelerin geliştirilme sürecinde her gruba verdiğim haftalık grup } \\
\text { proje değerlendirme raporu ve proje açıklama formunu inceleyip } \\
\text { gelişmelerini değerlendirebilirim. }\end{array}$ & 0.741 & \\
\hline $\begin{array}{l}\text { Proje çalışmalarında öğrencilerin kendini ve arkadaşlarını } \\
\text { değerlendirmelerini sağlayabilirim. }\end{array}$ & 0.673 & \\
\hline $\begin{array}{l}\text { Proje tabanlı öğretim yöntemini kullanırken bir problemle } \\
\text { karşılaştığımda ne yapacağımı bilemem. }\end{array}$ & 0.804 & \multirow{5}{*}{$\begin{array}{l}\text { 3. Faktörün } \\
\text { Açıkladığı Varyans : \%7 } \\
\text { Cronbach Alfa }=\mathbf{0 . 7 5}\end{array}$} \\
\hline $\begin{array}{l}\text { Proje kapsamında öğrencilerin bilgiye ulaşmak amacıyla elektronik } \\
\text { kaynakları nasıl kullanabileceklerini göstermek için bilgi altyapımın } \\
\text { yetersiz olduğunu düşünüyorum. }\end{array}$ & 0.667 & \\
\hline $\begin{array}{l}\text { Proje çalışmaları sırasında deney yaptırma konusunda yeterli } \\
\text { olmadığımı hissediyorum. }\end{array}$ & 0.665 & \\
\hline $\begin{array}{l}\text { Proje tabanlı öğretim uygulamalarında uygun değerlendirme ölçütleri } \\
\text { belirlemede zorluk çekerim. }\end{array}$ & 0.641 & \\
\hline $\begin{array}{l}\text { Grup projelerinde her bir öğrencinin performansını takip etmekte } \\
\text { zorlanırım. }\end{array}$ & 0.608 & \\
\hline Proje çalışmalarında süreyi etkili kullanabileceğimi düşünüyorum. & 0.753 & \multirow{3}{*}{$\begin{array}{l}\text { 4.Faktörün } \\
\text { Açıkladığı Varyans: } \% 5 \\
\text { Cronbach Alfa }=0.80\end{array}$} \\
\hline $\begin{array}{l}\text { Proje çalışmaları sırasında zaman yönetimiyle ilgili etkili stratejileri } \\
\text { kullanabilirim. }\end{array}$ & 0.735 & \\
\hline Öğrencilere proje tabanlı öğretim sürecinin özelliklerini tanıtabilirim. & 0.541 & \\
\hline $\begin{array}{l}\text { Öğrencilere proje çalışmaları sırasında ünite konularıyla ilgili farklı } \\
\text { bakış açıları kazandırabilirim. }\end{array}$ & 0.764 & \multirow{3}{*}{$\begin{array}{l}\text { 5.Faktörün } \\
\text { Açıkladığı Varyans: \%6 } \\
\text { Cronbach Alfa }=0.68\end{array}$} \\
\hline $\begin{array}{l}\text { Proje çalışmalarında öğrencilerin bilgiyi araştırıp önceki bilgileriyle } \\
\text { anlamlı bağlantılar kurmalarını sağlayabilirim. }\end{array}$ & 0.756 & \\
\hline Projelerde heterojen gruplar oluşturabilirim. & 0.542 & \\
\hline \multicolumn{3}{|c|}{$\begin{array}{l}\text { Ölçek İçin Açıklanan Toplam Varyans }=\% 66 \\
\text { Ölçek İçin Cronbach Alfa (Güvenirlik) }=\% 92 \\
\text { Kaiser-Mayer-Olkin (KMO) }=\mathbf{0 . 8 6 0} \\
\text { Barlett Testi Yaklaşık Ki-Kare }=\mathbf{3 2 5 9 . 4 2 2} \quad \mathbf{d f}=\mathbf{9 9 0} \quad \mathbf{p}<\mathbf{0 . 0 5} \\
\text { Ölçeğin analizleri sırasında Temel Bileşenler Analizi (Principal Component Analysis) kullanılmıştır. Varimax } \\
\text { döngüsü ile ölçekteki maddelerin } 5 \text { faktörde toplandığ1 sonucuna ulaşılmıştır. }\end{array}$} \\
\hline
\end{tabular}


Tablo 2. Ölçeğe Ait Faktörlerin Özdeğerler

\begin{tabular}{cc}
\hline Faktörler & Özdeğerleri \\
\hline $\mathbf{1}$ & 9.97 \\
$\mathbf{2}$ & 2.01 \\
$\mathbf{3}$ & 1.62 \\
$\mathbf{4}$ & 1.35 \\
$\mathbf{5}$ & 1.35 \\
\hline
\end{tabular}

Faktör sayısı hakkında daha kesin sonuç elde etmek için scree grafiği sunularak faktör sayısı ve özdeğerlerin belirtildiği sonuçlar Tablo 2'de verilmiştir. Şekil 1'e bakıldığında, grafik eğrisinin hızlı düşme eğilimini gösterdiği yer 5. faktörün bulunduğu yerdir. 5. faktörden sonraki eğride paralellik görülmektedir. Bu nedenle faktör yapısı 5 olarak tespit edilmiştir.

Tablo 3. Ölçekte Yer Alan Beş Faktör Arası Korelasyonlar

\begin{tabular}{lccccc}
\hline & FAKTÖR 1 & FAKTÖR 2 & FAKTÖR 3 & FAKTÖR 4 & FAKTÖR 5 \\
\hline FAKTÖR 1 & 1 & $0.625^{* *}$ & $0.439^{* *}$ & $0.532^{* *}$ & $0.502^{* *}$ \\
FAKTÖR 2 & $0.625^{* *}$ & 1 & $0.363^{* *}$ & $0.508^{* *}$ & $0.453^{* *}$ \\
FAKTÖR 3 & $0.439^{* *}$ & $0.363^{* *}$ & 1 & $0.447^{* *}$ & $0.357^{* *}$ \\
FAKTÖR 4 & $0.532^{* *}$ & $0.508^{* *}$ & $0.447^{* *}$ & 1 & $0.508^{* *}$ \\
FAKTÖR 5 & $0.502^{* *}$ & $0.453^{* *}$ & $0.357^{* *}$ & $0.508^{* *}$ & 1 \\
\hline
\end{tabular}

$* * \mathrm{p}<0.05$

Elde edilen faktör yapıları arasındaki korelasyon katsayıları Pearson Korelasyon analizi ile Tablo 3'de gösterildiği gibi elde edilmiştir. Faktörlerin aynı yapıyı ölçmesinin sınır değeri 0.70 olarak kabul edilmiştir (Cohen, 1988). Tablo 3, ölçekte yer alan beş faktör arasında tespit edilen ilişkilerin pozitif yönde olduğunu ve ölçeğin bağımsız fakat anlamlı düzeyde ilişkili faktörlerden oluştuğunu göstermektedir. Bu değerler de ölçeğin içyapısının homojen olduğunu ancak alt faktörlerin değişik yapıları ölçtüğünü kanıtlamaktadır ve ölçeğin geçerliğini yükseltmektedir.

\section{Sonuç, Tartışma ve Öneriler}

Öğretmenlerin genel öz yeterlilik inançları, belirli bir alandaki eğitimi verme yeteneklerine ilişkin inançlarını yeterince yansıtmayabileceğinden, öğretmenlerin özel alanlardaki özyeterliğinin saptanması önem taşımaktadır (Yılmaz, Köseoğlu, Gerçek, Soran, 2004). Özel öz yeterlilik (spesific self-efficacy) "bireyin verilen durumun taleplerine göre motivasyonu, bilgi kaynaklarını ve faaliyet yönünü harekete geçirme yeteneğine olan inancı" olarak tanımlanmaktadır (Wood ve Bandura, 1989). Bu kapsamda PTÖ uygulama öz yeterlilik inancı ise, "bireyin PTÖ uygulamasını uygun biçimde kullanma konusunda kendine ilişkin yargısı" veya "bireyin PTÖ uygulamasına dair inancı" olarak ifade edilebilir.

PTÖ sürecinin sağlkklı yürütülebilmesinin kuşkusuz en önemli bileşenlerinin başında öğretmenler gelmektedir. Öğretmenin sahip olduğu bilgi düzeyi, bu bilgi düzeyini karş1 tarafa ne derece aktarabildiği, eğitim ve öğretim yöntemlerine ne derece hakim olabildiği ve öğrencilerle iletişim düzeyi, bu konuda başarılı olabilme algısıyla önem kazanmaktadır. $\mathrm{Bu}$ nedenle öğretmenlerin bireysel gelişimlerini, eğitim-öğretim etkinliklerine ve kullandıkları yönteme yansıtma konusunda, özyeterlilik kavramı devreye girmektedir. En genel tanımıyla özyeterlilik, bireyin sonradan müdahale şansı olsun ya da olmasın, yapısında ve düşünme sisteminde var olan bir beceriyi temsil etmektedir. Buna göre özyeterlilik düzeyi, 
öğretmenlerin her birisine standart olarak verilmiş eğitim içeriğini ne derece içselleştirdiğinin ve etkin kullandığının bir göstergesidir.

Yapılan tüm bu geçerlik ve güvenirlik işlemleri ölçeğin, öğretmenlerin PTÖ yapabilme özyeterliliklerine ilişkin özyeterliliklerini saptamada geçerli ve güvenilir biçimde kullanılabilecek bir ölçme aracı olduğunu ortaya koymaktadır. Geliştirilen özyeterlilik ölçeği "Proje Sürecine Hâkimiyet, Rehberlik Etme", "Planlama, Hazırlık ve Yansitma", "Uygulama ve Değerlendirme", "Dönüt Verme, Alternatif Değerlendirme", "Grup Süreci ve Üst Düzey Öğrenme" boyutlarından oluşmaktadır.

$\mathrm{Bu}$ bağlamda öğretmenlerin sahip oldukları PTÖ yapabilme özyeterlilik düzeyleri bu yöntemin nasıl ve ne derece gerçekleşeceğinin de bir göstergesidir. Okul ortamlarındaki çalışmalarında söz konusu görevlerini yerine getirmeye çalışırken pek çok sorun ve engelle karşılaşabilen öğretmenlerin PTÖ özyeterlilik inançlarının genel olarak yüksek çıkması, bu engelleri aşabilmek için çaba gösterecek olmalarından dolayı önemlidir. Bu çalışmanın PTÖ'ye yönelik öğretmen davranışlarını anlama ve geliştirmeye katkı sağlayacağ düşünülmektedir. Ayrıca alanyazında öğrencilerin, öğretmenlerin ve öğretmen adaylarının PTÖ özyeterliliklerini belirlemeyi amaçlayan geçerli ve güvenilir herhangi bir ölçme aracına rastlanamamış olması, bu çalışmanın alanyazına katkı sağlayacağını göstermektedir.

Çalışma dikkate alındığında aşağıdaki önerilerde bulunulabilir:

-Öğretmenlerin PTÖ yapabilirliklerine ilişkin özyeterlilik algıları Türkiye genelindeki öğretmen ve öğretmen adaylarına uygulanarak farklı değişkenler açısından incelenebilir.

- Bundan sonraki çalışmalara yönelik olarak; öğretmenlerin PTÖ yaklaşımı hakkında ne kadar donanımlı oldukları, PTÖ yöntemini ne sıklıkla kullandıkları ve bu yöntemle işlenen konuların, öğrencilerin akademik başarısına etkisinin daha geniş ve farklı bölgelerdeki gruplar üzerinde araştırılması gerekli görülebilir.

- Öğretmenlerin başta PTÖ yaklaşımının uygulanmasında karşılaştıkları sorunlar olmak üzere, farklı öğrenme yaklaşımlarının uygulanmasında karşılaştıkları sorunları belirlemeye yönelik nitel-nicel araştırmalar yapılabilir. 
Ek: Proje Tabanlı Öğretime İliş̧kin Özyeterlilik Ölçeği

\begin{tabular}{|c|c|c|c|c|c|c|}
\hline \multirow{2}{*}{ 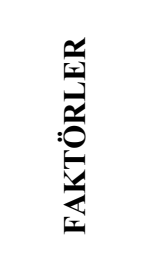 } & \multirow[t]{2}{*}{ İFADELER } & 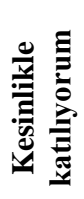 & ב̇ & $\underset{\Xi}{\mathbb{N}}$ & 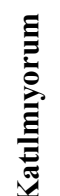 & 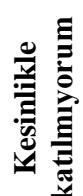 \\
\hline & & (5) & (4) & (3) & (2) & (1) \\
\hline \multirow{9}{*}{ 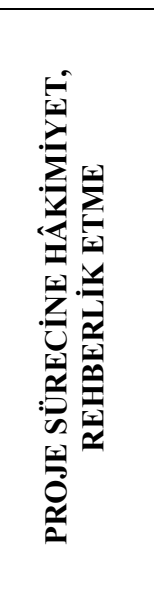 } & $\begin{array}{l}\text { 1. Öğrencilere, kazandıkları farklı becerileri kullanabilecekleri proje } \\
\text { calısmaları hazırlatabilirim. }\end{array}$ & & & & & \\
\hline & $\begin{array}{l}\text { 2. Öğrencilerimi proje çalışmaları sonunda özgün ürünler üretmeye } \\
\text { teşvik edebilirim. }\end{array}$ & & & & & \\
\hline & $\begin{array}{l}\text { 3. Öğrencilerimin eksiklerini tamamlamaları ve yanlışlarını düzeltmeleri } \\
\text { için etkili bir biçimde rehberlik edebilirim. }\end{array}$ & & & & & \\
\hline & $\begin{array}{l}\text { 4. Proje çalışmaları sırasında öğrencilerin edindikleri bilgileri } \\
\text { düzenlemeye yardım edebilirim. }\end{array}$ & & & & & \\
\hline & $\begin{array}{l}\text { 5. Proje gruplarının araştırma ve çalışma becerilerinin geliştirilmesine } \\
\text { yardım ve rehberlik edebilirim. }\end{array}$ & & & & & \\
\hline & 6. Öğrencileri yeni projeler üretmeleri konusunda motive edebilirim. & & & & & \\
\hline & $\begin{array}{l}\text { 7.Öğrencilerin projeleri sonunda öğrencilerin eksikliklerini } \\
\text { tamamlayabilirim. }\end{array}$ & & & & & \\
\hline & $\begin{array}{l}\text { 8. Proje tabanlı öğretim uygulamalarında bireysel olarak öğrencilerin } \\
\text { araştırma ve çalışma becerilerini geliştirebilirim. }\end{array}$ & & & & & \\
\hline & 9. Projelerde tüm aşamaları sırasıyla yerine getirebilirim. & & & & & \\
\hline \multirow{4}{*}{ 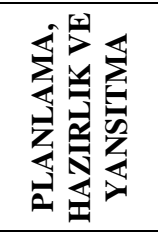 } & 10. Proje çalışmalarında süreyi etkili kullanabileceğimi düşünüyorum. & & & & & \\
\hline & $\begin{array}{l}\text { 11. Proje çalışmaları sırasında zaman yönetimiyle ilgili etkili stratejileri } \\
\text { kullanabilirim. }\end{array}$ & & & & & \\
\hline & 12. Öğrencilere proje tabanlı öğretim sürecinin özelliklerini tanıtabilirim. & & & & & \\
\hline & $\begin{array}{l}\text { 13. Proje çalışmalarında öğrencilerin kendini ve arkadaşlarını } \\
\text { değerlendirmelerini sağlayabilirim. }\end{array}$ & & & & & \\
\hline \multirow{5}{*}{ 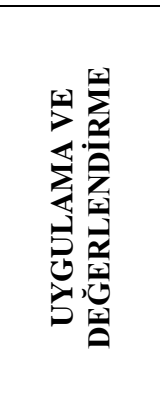 } & $\begin{array}{l}\text { 14. Proje tabanlı öğretim yöntemini kullanırken bir problemle } \\
\text { karşılaştığımda ne yapacağımı bilemem. }\end{array}$ & & & & & \\
\hline & $\begin{array}{l}\text { 15. Proje kapsamında öğrencilerin bilgiye ulaşmak amacıyla elektronik } \\
\text { kaynakları nasıl kullanabileceklerini göstermek için bilgi altyapımın } \\
\text { yetersiz olduğunu düşünüyorum. }\end{array}$ & & & & & \\
\hline & $\begin{array}{l}\text { 16. Proje çalışmaları sırasında deney yaptırma konusunda yeterli } \\
\text { olmadığımı hissediyorum. }\end{array}$ & & & & & \\
\hline & $\begin{array}{l}\text { 17. Proje tabanlı öğretim uygulamalarında süreç içerisinde uygun } \\
\text { değerlendirme ölçütleri belirlemede zorluk çekerim. }\end{array}$ & & & & & \\
\hline & $\begin{array}{l}\text { 18. Grup projelerinde her bir öğrencinin performansını takip etmekte } \\
\text { zorlanırım. }\end{array}$ & & & & & \\
\hline \multirow{3}{*}{ 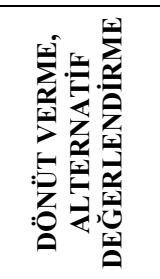 } & $\begin{array}{l}\text { 19. Öğrencilere proje oluşturmanın her aşaması ile ilgili geri bildirim } \\
\text { verebilirim. }\end{array}$ & & & & & \\
\hline & $\begin{array}{l}\text { 20. Proje kapsamında öğrencilerin hazırladıkları portfolyoları } \\
\text { değerlendirebilirim. }\end{array}$ & & & & & \\
\hline & $\begin{array}{l}\text { 21. Projelerin geliştirilme sürecinde her gruba verdiğim haftalık grup } \\
\text { proje değerlendirme raporu ve proje açıklama formunu inceleyip } \\
\text { gelişmelerini değerlendirebilirim. }\end{array}$ & & & & & \\
\hline \multirow{3}{*}{ 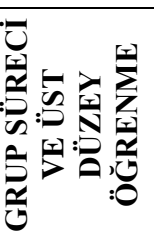 } & $\begin{array}{l}\text { 22. Öğrencilere proje çalışmaları sırasında ünite konularıyla ilgili farklı } \\
\text { bakış açıları kazandırabilirim. }\end{array}$ & & & & & \\
\hline & $\begin{array}{l}\text { 23. Proje çalışmalarında öğrencilerin bilgiyi araştırıp önceki bilgileriyle } \\
\text { anlamlı bağlantılar kurmalarını sağlayabilirim. }\end{array}$ & & & & & \\
\hline & 24. Projelerde heterojen gruplar oluşturabilirim. & & & & & \\
\hline
\end{tabular}




\section{KAYNAKÇA}

AKGÜN, Ş. (2004). Fen Bilgisi Öğretimi. Ankara: Nasa Yayınevi.

AKSOY, V. \& DİKEN, I. H. (2009). Examining school counselors' sense of self-efficacy regarding psychological counsultation and counseling in special education. Elementary Education Online, 8(3), 709-719.

ALTUNIŞIK, R., COŞKUN, R., BAYRAKTAROĞLU, S. ve YILDIRIM, E. (2005). Sosyal Bilimlerde Araştırma Yöntemleri: SPSS Uygulamalı. Sakarya: Sakarya Kitabevi.

AYDEMIR, H., DURAN, M., KAPIDERE, M., KALECI, D. ve AKSOY, D. N. (2014). Selfefficacy of teacher candidates. Intended teaching profession. Procedia-Social and Behavioral Sciences, 152, 161-166.

AYVACI, H. Ş. ve ÇORUHLU, T. Ş. (2010). Fen ve teknoloji dersi proje tabanlı öğrenme uygulamasında ilköğretim öğrencilerinin karşılaştıkları güçlükler. Uludağ Üniversitesi Eğitim Fakültesi Dergisi, 23(1), 43-59.

BANDURA, A. (1982). Self-efficacy mechanism in human agency. American Psychologist, $37,122-147$.

BANDURA, A. (1997). Self-efficacy: The exercise of control. New York: Freeman.

BÜYÜKÖZTÜRK, Ş. (2007). Sosyal bilimler için veri analizi el kitabı. Ankara: Pegem A Yayıncilik.

COHEN, J. (1988). Statistical power analysis for the behavioral sciences. New York, NY: Routledge Academic.

ÇAPRİ, B. ve ÇELİKKALELİ, Ö. (2008). Öğretmen adaylarının öğretmenliğge ilişkin tutum ve mesleki yeterlik inançlarının cinsiyet, program ve fakültelerine göre incelenmesi. İnönü Üniversitesi Eğitim Fakültesi Dergisi, 9(15), 33-53.

EKİCI, G. (2006). Meslek lisesi öğretmenlerinin öğretmen öz-yeterlik inançları üzerine bir araştırma. Eğitim Araştırmaları, 8, 87-96.

ELKATMIŞ, M., DEMİRBAŞ, M. ve ERTUĞRUL, N. (2013). Eğitim fakültesi öğrencileri ile formasyon eğitimi alan fen edebiyat fakültesi öğrencilerinin öğretmenlik mesleğine yönelik öz yeterlik inançları. Pegem Ĕ̈itim ve Öğretim Dergisi, 3(3), 41-50.

ERDEM, M. (2002). Proje tabanlı öğrenme. Hacettepe Üniversitesi Eğitim Fakültesi Dergisi, 22, 172-179.

GENÇTÜRK, A. ve MEMIŞ, A. (2010). İlköğretim okulu öğretmenlerinin öz yeterlik algıları ve iş doyumlarının demografik faktörler acısından incelenmesi. Illköğretim Online, 9(3), 1037- 1054.

KIVRAK, E., ve DÖNMEZ, S. (2013). Sınıf öğretmenlerinin fen ve teknoloji dersi özyeterlilik inançlarının denetim odağına göre farklılığının incelenmesi. Erzincan Üniversitesi Fen Bilimleri Enstitüsü Dergisi, 6(1), 13-38.

KLINE, P. (1994). An easy guide to factor analysis. New York: Routledge. 
KORKMAZ, H. (2004). Fen ve teknoloji eğitiminde alternatif değerlendirme yaklaşımlarl. Ankara: Yeryüzü Yayınevi.

KUTLUCA, A. Y. ve AYDIN, A. (2016). Fen bilgisi öğretmen adaylarının öz-yeterlik inançlarının çeşitli değişkenler açısından incelenmesi: oluşturmacı öğretimin etkisi. Abant İzzet Baysal Üniversitesi Ĕ̈itim Fakültesi Dergisi, 16(1), 217-236.

MERGENDOLLER, J. R. \& THOMAS, J. W. (2001). "Managing project-based learning: Principles from the Field." Buck Institute for Education. Paper available on-line: (http://www.bie.org)

NAKİP, C. ve ÖZCAN, G. (2016). Öğretmen adaylarının öğretmenlik mesleğine yönelik özyeterlik inançları ile öğretmenlik mesleğine yönelik tutumları arasındaki ilişki. Mersin Üniversitesi Ĕ̈itim Fakültesi Dergisi, 12(3), 783-795.

ÖZDEMIR, S. M. (2008). Sınıf öğretmeni adaylarının öğretim sürecine ilişkin öz-yeterlik inançlarının çeşitli değişkenler açısından incelenmesi. Kuram ve Uygulamada Eğitim Yönetimi, 54, 277-306.

PEKTAŞ, H.M. ve ARSLAN, M. M. (2009). Fen ve teknoloji öğretmenlerinin proje tabanlı öğretim uygulamalarında karşılaşılan sorunlara katılma düzeyleri. Çağdaş Eğitim Dergisi, 34(367), 3-12.

SERT ÇIBIK, A., INCE AKA, E. ve KAYACAN, K. ( 2016). Genel fizik laboratuvar1-II dersinde kullanılan proje tabanlı öğretim yönteminin öz-yeterlik, tutum ve başarıya etkisi. Kastamonu Ĕ̈itim Dergisi, 24(1), 511-534.

TATLIDİL H. (2002). Uygulamalı Çok Değişkenli İstatistiksel Analiz, Akademi Matbaası, Ankara.

TAVŞANCIL, E. (2002). Tutumların Ölçülmesi ve SPSS ile Veri Analizi. Ankara: Nobel.

TEZBAŞARAN, A. (2008). Likert tipi ölçek hazırlama kılavuzu. Mersin: Türk Psikologlar Derneği.

TSAİ, L.S. ve CHAI, K. S. (2005). Developing and validating a nursing website evaluation questionnaire, Methodological Issues in Nursing Research, 49(4), 416-413.

TSCHANNEN-MORAN, M. \& WOOLFOLK HOY, A. (2001). Teacher efficacy: Capturing an elusive construct. Teaching and Teacher Education, 17, 783-805.

UYSAL, İ. ve KÖSEMEN S. (2013). Öğretmen adaylarının genel öz-yeterlik inançlarının incelenmesi. Ĕgitim ve Öğretim Araştırmaları Dergisi, 2(2), 217-226.

UZUN, Ç. (2007). İlkögrretim 4. ve 5. sinıf fen ve teknoloji dersi, canlılar dünyasinı gezelim tanıyalım ünitesinde proje tabanlı ögretimin akademik başarı ve kalıcılı̆̆a etkisi. Yüksek Lisans Tezi, Afyonkocatepe Üniversitesi Sosyal Bilimler Enstitüsü, Afyonkarahisar.

WOOD, R. E. \& BANDURA, A. (1989). Social cognitive theory of organizational management. Academy of Management Review, 14, 361-384. 
YAMAN, S. (2005). Fen bilgisi eğitiminde probleme dayalı öğrenmenin mantıksal düşünme becerisinin gelişimine etkisi. Türk Fen Eğitim Dergisi, 2(1), 56-70.

YAVUZ, S. (2005). Developing a technology attitude scale for pre-service chemistry teachers. The Turkish Online Journal of Educational Technology, 4(1), 17-25.

YEŞiLYURT, E. (2013). Öğretmen adaylarının öğretmen öz-yeterlik algıları. Elektronik Sosyal Bilimler Dergisi, 12(45), 88-104.

YILMAZ, M., KÖSEOĞLU, P., GERÇEK, C. ve SORAN, H. (2004). Yabancı dilde hazırlanan bir öğretmen öz-yeterlik ölçeğinin türkçe'ye uyarlanması. Hacettepe Üniversitesi Eğitim Fakültesi Dergisi, 27, 260-267.

ZIMMERMAN, B. J. (1995). Self-regulation involves more than metacognition: A social cognitive perspective. Educational Psychologist, 30, 217-221. 